\title{
A Kétlépcsős Integrált Alkalmasságvizsgálati Rendszer - a tudomány válasza a rendvédelmi hivatásos állomány alkalmasságvizsgálatának kihívásaira
}

\author{
The Two-stage Integrated Aptitude Testing System - \\ as a response of science to the challenges of aptitude assessment \\ of law enforcement professional staff
}

\begin{abstract}
Absztrakt
Számos nemzetközi és hazai kutatás igazolja, hogy minden olyan munka, melyet a belügyi rendvédelmi szervek hivatásos állománya végez, fokozott egészségi, pszichikai és fizikai megterheléssel jár. Mindez elengedhetetlenné és egyben kiemelt fontosságúvá teszi a hivatásos állomány alkalmasságvizsgálati rendszerét. Egy ilyen rendszer hatékonyságának alapvető feltétele, hogy folyamatosan igazodjon a szervezeti igényekben, valamint a szervezethez jelentkezők jellemzőiben bekövetkező változásokhoz. A digitalizáció és a világháló használatának robbanásszerü megnövekedése jelentette rendvédelmi kihívások, valamint a fiatal generáció megváltozott képességei és munka iránti motivációja törvényszerúen vonta maga után a rendvédelmi hivatásos állomány több, mint tíz éves alkalmasságvizsgálati rendszerének felülvizsgálatát.

Ezen kihívásokra adott válaszként született meg a Kétlépcsős Integrált Alkalmasságvizsgálati Rendszer (röviden: KLIR), melyet a belügyminiszter irányítása alatt álló egyes rendvédelmi szerveknél foglalkoztatott hivatásos állomány és rendvédelmi igazgatási alkalmazotti állomány alkalmasságvizsgálatáról szóló 45/2020. (XII.16.) BM. rendelet 2021. január 1-jével kötelező érvénnyel bevezetett. Tanulmányunkban a KLIR rendszer tudományos megalapozását ismertetjük a rendszer legfontosabb alapelvei mentén tárgyalva.

Bemutatjuk, hogy a KLIR rendszer két lépcsőfoka - a munka és az egyén illeszkedését több szinten vizsgálva - miként szolgálja az alkalmatlanok kiszürésén
\end{abstract}


túl a leginkább alkalmas jelölt kiválasztását, ezen keresztül pedig az egyéni és szervezeti hatékonyságot. A szervezeti hatékonyság egyik kulcsának tekintett rugalmas alkalmazkodóképesség jegyében ismertetjük a KLIR rendszer újításaiban, az alkalmasságvizsgálati kategóriák rendszerében, a háromszintủ szabályozási rendben, valamint az alkalmasságvizsgálatok és a továbbképzési rendszer összekapcsolásában rejlő lehetőségeket. A cikket a célzott tudományos kutatásnak a KLIR rendszer kialakításában játszott szerepének ismertetése, valamint a vonatkozó jövőbeni perspektívák felvillantása zárja.

Kulcsszavak: egészségi, pszichológiai és fizikai alkalmasságvizsgálat, rendvédelem, hivatásos állomány, Kétlépcsős Integrált Alkalmasságvizsgálati Rendszer

\begin{abstract}
Numerous international and domestic studies have shown that all the duties which law enforcement personnel perform put an increased strain of mental and physical health. All this makes the aptitude testing system of the professionals essential and at the same time more important. An essential condition for the effectiveness of such a system is to be able to continuously adapt to changes in organizational needs and the characteristics of applicants for the organization. The explosive growth in digitalization and the use of the World Wide Web has posed a revision of the more than ten years applied aptitude test system for law enforcement professionals as law enforcement challenges and the younger generation's changed abilities and motivation to work.

In response to these challenges, the Two-stage Integrated Aptitude Testing System (abbreviated as KLIR) was established by Decree No. 45/2020 on the suitability assessment of professional staff and law enforcement administrative staff employed by certain law enforcement agencies under the Minister of the Interior. (XII.16.) BM. Regulation entered into force on 1 January 2021. In our study, we describe the scientific basis of the KLIR system, discussing it along the most important principles of the system.

We show how the two steps of the KLIR procedure-examining the fit of work of individuals on several levels at the same time - serving the selection of the most suitable candidates and in addition to the screening of unsuitable ones, thereby improving individual and organizational performance. In the spirit of flexible adaptability, which is considered to be one of the keys to organizational efficiency, we describe the possibilities of the innovations of the KLIR procedure, the scheme of aptitude test categories, the three-level regulatory order, and the coherency between aptitude tests and the training system. The article concludes with
\end{abstract}


a description how the targeted scientific research has contributed to the development of the KLIR system and provides a glimpse of relevant future perspectives.

Keywords: health, psychological and physical aptitude test, law enforcement, professional staff, Two-stage Integrated Aptitude Testing System

\section{Elözmények és problémafelvetés}

A munkavédelemi törvény ${ }^{1}$ értelmében minden munkáltató köteles gondoskodni az egészséget nem veszélyeztető és biztonságos munkavégzés feltételeiről. E kötelezettség teljesítésének egyik legfontosabb eleme, hogy a munkavállaló adott munkakörben csak akkor alkalmazható, ha foglalkoztatása önmaga vagy mások egészségét, testi épségét nem veszélyezteti. A belügyi rendvédelmi szervek hivatásos állománya esetében a munkaköri alkalmasságvizsgálatok különös jelentőséggel és egyben specifikus jellemzőkkel bírnak. Számos nemzetközi és hazai kutatás igazolja, hogy minden olyan munka, melyet a belügyi rendvédelmi szervek hivatásos állománya végez fokozott egészségi, pszichikai és fizikai megterheléssel jár (Atkinson, R. L., Atkinson, R. C., Smith \& Bem, 1999; Johnson et al., 2005; Queirós et al., 2020). Éppen ezért kiemelten fontos, ebből adódóan pedig alapvető elvárás, hogy csak és kizárólag olyan kollégák kerüljenek felvételre a hivatásos állományba, akik alkalmasak ezen fokozott megterhelést jelentő feladatok elvégzésére, valamint ezen munka hosszútávú végzése során is képesek megőrizni az alkalmasságukat, ezen keresztül pedig a testi-lelki egészségüket.

Az alkalmasságvizsgálatok rövid történeti áttekintéseként érdemes megemlíteni, hogy már a fegyveres szervek hivatásos állományú tagjainak szolgálati viszonyáról szóló 1996. évi XLIII. törvény 75. §-ában is szerepelt a következő elvárás:

„(1) A hivatásos állomány tagjának meg kell felelnie a miniszter által meghatározott, a beosztásának és életkorának megfelelö egészségi, pszichikai és fizikai alkalmassági követelményeknek. Az alkalmasság elérésének és szinten tartásának feltételeit a fegyveres szerv biztositja."

Ennek szellemében először a 33/1997. IM-BM-TNM együttes rendelet kísérelte meg ötéves türelmi idővel szabályozni a pszichológus által a rendőrségen ellátandó feladatokat, valamint azok végrehajtását és végrehajtatását. Még a türelmi idő lejárta, illetve a rendőri szervek hathatós reakciója előtt követte ezt a rendeletet a 21/2000. (VIII. 23.) IM-BM-TNM együttes rendelet a fegyveres

1 1993. évi XCIII. törvény a munkavédelemről. 
szervek hivatásos, közalkalmazotti és köztisztviselői állományának munkaköri egészségi, pszichikai és fizikai alkalmasságáról, a szolgálat-, illetve keresőképtelenség megállapításáról, valamint a belügyi egészségügyi szolgálat igénybevételéről, mely a türelmi időt eltörölve pontosította az elvégzendő feladatokat és bizonyos pszichológiai feladatok, elsősorban különböző alkalmassági vizsgálatok azonnali bevezetését és végrehajtását határozta meg (Pásztor \& Szabó, 2005).

A rendeletet megjelenése után számtalanszor módosították a szervezeti változásoknak, valamint a felmerülő újabb és újabb igényeknek való megfelelés érdekében. Végül kilenc év után született meg az újabb, az 57/2009. (X. 30.) IRM-ÖM-PTNM együttes rendelet az egyes rendvédelmi szervek hivatásos állományú tagjai egészségi, pszichikai és fizikai alkalmasságáról, közalkalmazottai és köztisztviselői munkaköri egészségi alkalmasságáról, a szolgálat-, illetve keresőképtelenség megállapításáról, valamint az egészségügyi alapellátásról, mely egységes keretbe foglalta a különböző alkalmasságvizsgálatokat, valamint több, mint 150 oldalas mellékletében részletesen ismertette a rendvédelmi szerveknél rendszeresített különböző beosztásokhoz tartozó egészségi, pszichikai és fizikai alkalmassági követelményeket.

Az együttes rendelet bevezetése óta eltelt újabb tíz év, melynek során felgyülemlett tapasztalat egyértelmủen szükségessé tette azt, hogy ismételten felülvizsgálatra kerüljön a rendvédelmi hivatásos állomány alkalmasságvizsgálati rendszere a benne szereplö követelményekkel együtt. Ezt támasztotta alá az a tény is, hogy főként a digitalizáció, valamint a világháló használatának következményeként átalakultak a rendvédelmi szervek egyes beosztásaival (például kiber- és gazdasági nyomozó stb.) kapcsolatos elvárások, miközben változtak a rendvédelmi szervekhez jelentkező fiatalok motivációi, képességei és kompetenciái is. Ezen különböző irányból érkező hatások együttes eredőjeként dr. Pintér Sándor belügyminiszter 2018-ban elvárásként fogalmazta meg a rendvédelmi szervek hivatásos állománya számára kötelező alkalmasságvizsgálati rendszer megújítását. Az új alkalmasságvizsgálati rendszer koncepciójának kialakítása során természetesen figyelemmel kellett lenni az alkalmasságvizsgálati rendszert megalapozó, valamint az azzal szoros kapcsolatban álló szabályozókra és rendszerekre is, mint:

- a rendvédelmi feladatokat ellátó szervek hivatásos állományának szolgálati jogviszonyáról szóló 2015. évi XLII. törvényre (a továbbiakban: Hszt.);

- a megváltozott egészségi állapotú hivatásos állományú kollégák alkalmasságvizsgálatának felülvizsgálati rendszerére;

- valamint a rendvédelmi egészségkárosodási ellátás rendszerére².

2 54/2016. (XII. 22.) BM rendelet a belügyminiszter irányítása alatt álló rendvédelmi feladatokat ellátó szerveknél alkalmazható rendvédelmi egészségkárosodási ellátásról. 
Alapvető elvárásként fogalmazódott meg az is, hogy az új rendszer egyszerü, költségkímélö, és egyben alacsony eszközigényü legyen, mely képes nagy létszámú jelentkező mérésére is. Ehhez szorosan kapcsolódva a fejlesztési, képzési rendszer megerősítése és újragondolása is szükségessé vált. Nem új jogintézmények, illetve rendszerek bevezetése volt a cél, hanem a rendelkezésre álló képzési, továbbképzési rendszer optimalizálása, illetve az egyéni igényekhez és a szervezeti elvárásokhoz együttesen igazodni képes fejlesztése. Mindez természetesen elképzelhetetlen volt egy kapcsolódó, az új rendszer müködtetését támogató informatikai rendszer kialakítása nélkül.

A fentiekben megfogalmazott elvárásoknak eleget téve született meg a Kétlépcsős Integrált Alkalmasságvizsgálati Rendszer (röviden: KLIR), mely a gyakorlat kérdéseire tudományos igényességgel kereste a válaszokat, és igyekezett integrálni minden olyan vonatkozó kutatási eredményt, mely a szakemberek rendelkezésére állt. A KLIR rendszert a belügyminiszter irányítása alatt álló egyes rendvédelmi szerveknél foglalkoztatott hivatásos állomány és rendvédelmi igazgatási alkalmazotti állomány alkalmasságvizsgálatáról szóló 45/2020. (XII.16.) BM rendelet (a továbbiakban: Rendelet) 2021. január 1-jével kötelező érvénnyel bevezette az általános rendőrségi feladatok ellátására létrehozott szerv, a belső bünmegelőzési és bünfelderítési feladatokat ellátó szerv, a terrorizmust elhárító szerv, az idegenrendészeti szerv, a hivatásos katasztrófavédelmi szerv és a büntetés-végrehajtási szerv állományára vonatkozóan.

Tanulmányunkban a KLIR rendszer tudományos megalapozását ismertetjük a rendszer legfontosabb alapelveinek mentén tárgyalva.

\section{A legjobbak kiválasztása az alkalmatlanok kiszürésén túl}

A munkaköri alkalmassági vizsgálat lényege annak megállapítása, hogy egy meghatározott munkakörben és munkahelyen végzett tevékenység által okozott megterhelés a vizsgált személynek milyen igénybevételt jelent, és annak képes-e megfelelni. A vizsgálatok célja minden esetben a munkahelyi egészségkárosodások - foglalkozási betegségek, munkabalesetek - egészségügyi és pszichológiai megelőzése. A munkaköri alkalmassági vizsgálatok különböző jellegüek lehetnek, így megkülönböztetünk előzetes (munkakezdést megelőző, illetve felvétel előtti), időszakos (már munkaviszonyban lévők ismételt) és soron kívüli (egészségi állapot változáskor) alkalmassági vizsgálatokat.

A belügyi rendvédelmi szervek esetében az alkalmasságvizsgálatok során a legfontosabb vizsgálandó kérdés a hivatásos állományba való felvételre jelentkező személlyel kapcsolatban, hogy rendelkezik-e azokkal a minimális fizikai, 
pszichikai és egészségi jellemzőkkel, melyek szükségesek ahhoz, hogy legalább átlagos színvonalon képes legyen ellátni a jövőbeni feladatát. Már ebből a megfogalmazásból is jól látható, hogy a rendvédelmi szervek hivatásos állománya vonatkozásában az alkalmasságvizsgálatok célja túllép az általános munkaköri alkalmassági vizsgálatokon azzal, hogy az egészség megőrzésén túl a hatékony munkavégzés támogatását is célul tüzi ki.

Ezt hangsúlyozza a rendvédelmi szerveknél müködő egészségügyi és pszichológiai szolgálatok által végzett tevékenységekre vonatkozóan kidolgozott tevékenységi alapmodell (Malét-Szabó, 2015) is. A modell célmátrixában az egészség és hatékonyság egy dimenzió két végpontjaként szerepel, melyek mindegyike esetében egyaránt megjelenhet az egyéni és a szervezeti szintet célzó tevékenység. Hangsúlyozandó ugyanis, hogy mind az egészség, mind pedig a hatékonyság vonatkozásában az egyéni szinten túlmutató szervezeti szintről is beszélhetünk, melyek természetesen épp olyan szoros kapcsolatban állnak egymással, mint az egészség és hatékonyság célkitüzése. A modell 2x2-es célmátrixának mindegyik eleme kölcsönös és egyben dinamikus interakcióban van a többi elemmel, a rendvédelmi szervek egészségügyi és pszichológiai tevékenysége ezek együttes figyelembevételével képes az igazán hatékony, és egyben a szervezet egészének egészségét is támogató müködésre. A modell egyik jellemző pozitívuma, hogy az alkalmasságvizsgálatokkal együtt, egy közös rendszerbe integrálva tárgyalja a rendvédelmi szerveknél folyó egészségügyi és pszichológiai tevékenység teljes spektrumát, ezzel is jelezve, hogy az alkalmasságvizsgálatok számos egyéb tevékenységhez - mint például a gondozás, képzés - szervesen kapcsolódnak, melyekkel szorosan együttmúködve képesek egy valóban komplex és hatékony rendszer részévé válni (Malét-Szabó, 2020a).

1. számú ábra: Az egészség és hatékonyság célmátrixa

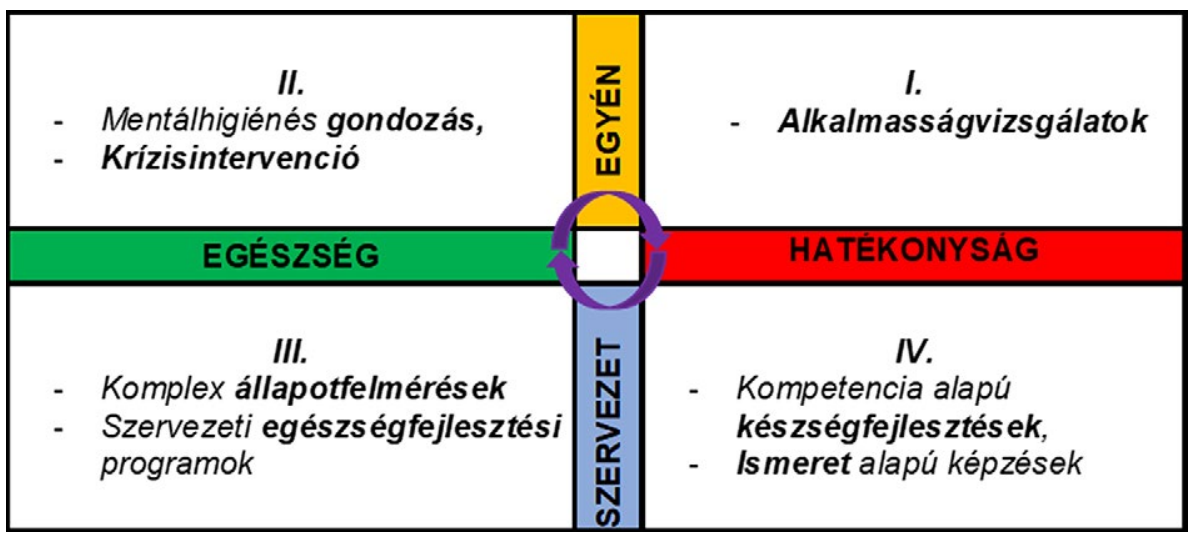

Forrás: Malét-Szabó, 2020a.

1390 Malét-Szabó Erika -Takács-Fehér Mária: A Kétlépcsős Integrált Alkalmasságvizsgálati Rendszer a tudomány válasza a rendvédelmi hivatásos állomány alkalmasságvizsgálatának kihívásaira 
Az egyén és a szervezet többszintü kapcsolatát és egymásra hatását támasztják alá a szervezeti hatékonyság szemszögéből a személy-munka megfelelés (Person-Job Fit) 1980-as, 1990-es években elterjedt modelljei (Juhász, 2006) is, melyek felhívták a figyelmet arra, hogy pusztán a végzendő feladat végrehajtására való alkalmasság vizsgálata, azaz az egyén képességeinek és készségeinek az illesztése a munka követelményeihez önmagában nem képes hatékonyan megjósolni az egyén jövőbeni beválását. Mindebben ugyanis igen fontos tényezőként vesz részt maga az egyén is, hiszen az egyénnek a vizsgált munkával kapcsolatos elvárásai, valamint az, hogy mindezek milyen összhangban vannak a munka által az egyén számára kínált lehetőségekkel, alapvetően befolyásolják a jövőbeni teljesítményét, illetve azt a tényt, hogy mennyi ideig marad az adott szervezetnél, mely utóbbi szintén igen fontos kérdése a beválásnak. Érdekességként megjegyzendő, hogy a munkaadottságok objektív és a személy szubjektív jellemzői közötti dinamikus összhang szükségességét Csirszka János már 1966-ban megfogalmazta (Csirszka, 1966). Ő ezen összeillés kapcsán három szintet különböztetett meg: a munkaprofil és az egyén képességei-készségei, a munka érzelmi adottságai és az egyén affektív adottságai, valamint a munka dinamizmusa és az egyén motivációi közötti összeillést. Ugyanezen többszintü illeszkedés fontosságát támasztja alá a Michigani Egyetem kutatóinak a munka és az egészség kapcsolatát tárgyaló személy-környezet illeszkedése modellje (2. számú ábra; Harrison, 1978) is, mely szerint, ha a személy képességei és igényei nem illeszkednek a konkrét munka jellegéhez és körülményeihez az munkahelyi feszültséget eredményez. Mindez pedig egyértelmúen negatív hatással van az egyén - és rajta keresztül a szervezet - mentális és fizikai egészségi állapotára, ami hosszabb távú fennállás esetén akár akut vagy krónikus betegség kialakulásához is vezethet.

2. számú ábra: A személy-környezet illeszkedése modell

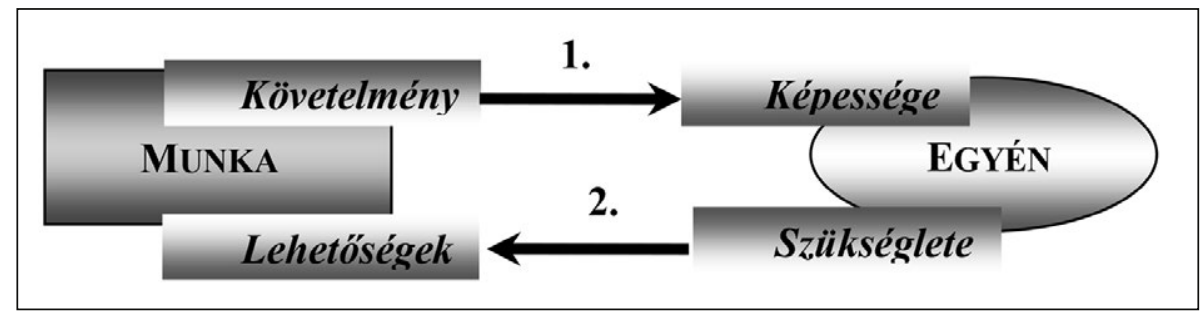

Forrás: Malét-Szabó, 2015.

Fontos megemlíteni, hogy az egyén és a munka közötti összecsiszolódást a szelekciós és szocializációs folyamatok egyaránt szolgálják. A szelekciót középpontba helyező elméletek a fő hangsúlyt az egyénre, az egyén személyiségjellemzőinek 
a megismerésére helyezik, célul pedig bizonyos prediktorok (a beválás előrejelzésére használt mutatók) segítségével a jövőbeni beválás mértékének megbecslését tüzik ki. Ezzel szemben a szocializációs folyamatot hangsúlyozó elméletek az új kollégák munkahelyi beillesztését tartják elsődlegesen fontosnak. Minden jelentkezőt potenciális kollégának tekintenek, és az egyénben rejlő potenciálokra, erőforrásokra és tanulási képességre fókuszálnak (Juhász, 2006). Ez utóbbi megközelítésnek a Magyar Honvédségre adaptált szemléletes példáját mutatja be tanulmányában Barna (2020), melyben felhívja a figyelmet arra, hogy még egy olyan hierarchizált, és több szempontból rugalmatlannak tekinthető szervezetben is, mint a Magyar Honvédség, milyen pozitív hatása lehet a szervezeti hatékonyságra a szelekciós folyamattal szinte párhuzamosan induló tudatos szervezeti szocializációnak.

Összegezve valószínűsíthető, hogy a beválást leginkább e két megközelítés ötvözésével tudjuk szolgálni, azaz akkor, ha egy jól kialakított szelekciós rendszert párosítunk egy olyan munkahelyi szocializációs folyamattal, mely képes az egyén képességeit is figyelembe véve illeszteni öt a munkahelyi szervezethez, miközben folyamatosan törekszik arra, hogy az egyénben rejlő erőforrások és lehetőségek hasznosításán, illetve fejlesztésén keresztül növelje a szervezeti hatékonyságot.

A rendvédelmi szervek hivatásos állománya számára kötelező alkalmasságvizsgálatok kapcsán 2020-ig szinte kizárólag azt a kérdést vizsgálták a szakemberek, hogy a pályázó egyén vajon mentes-e azoktól a személyiségjellemzőktől és betegségektől, melyek alkalmatlanná tennék őt a hivatásos állományú munkára. Ennek érdekében az alkalmasságvizsgálatok során a pszichológusok, az orvosok és a sportszakemberek elsősorban bizonyos betegségek, illetve kóros állapotok meglétét kutatták, illetve azt vizsgálták, hogy az egyén teljesítménye a pszichológiai tesztekben, valamint a különböző fizikai gyakorlatokban eléri-e azt a minimális szintet, melynek teljesítését az egyes beosztásokra vonatkozóan alapvető feltételként határoztak meg. Az alkalmasságvizsgálatok során kapott eredményeket 2020-ig ezen túlmenően - például az egyének jövőbeni beválási mértékének megbecslése érdekében - sem a szakemberek, sem pedig az állomány felvételére jogosult vezetők nem hasznosították. Önmagában azonban egy bizonyos kritériumszint teljesítése, avagy az adott beosztás szempontjából kockázatos betegségek hiánya még nem jelenti maradéktalanul azt, hogy az egyén a vágyott beosztásban valóban jól fog teljesíteni, illetve arra a kérdésre sem tud választ adni, hogy több jelentkező közül, vajon ki lenne az, aki a leginkább megfelelne az adott beosztásra. A tudatos HR tervezéshez, valamint a megalapozott munkáltatói döntéshez mindezen kérdések megválaszolása azonban elengedhetetlen.

Mindennek a megvalósítása érdekében, valamint, hogy eleget tehessünk a fentiekben megfogalmazott elvárásoknak szinte törvényszerú volt egy olyan új 
alkalmasságvizsgálati rendszer kialakítása, mely két lépcsőben igyekszik minden vonatkozó kérdésre választ kapni az egyén és a munka illeszkedése kapcsán. A KLIR rendszerben az alkalmasságvizsgálat első lépcsőjeként - megőrizve a korábbi alkalmasságvizsgálatok szemléletét és egyben eleget téve annak az alapvető elvárásnak, hogy a rendvédelmi szervek hivatásos állományába csak és kizárólag arra alkalmas egyének kerüljenek - az alkalmasságnak a teljes hivatásos állományra vonatkozóan kötelezően teljesítendő, úgynevezett minimumfeltételei, valamint a betöltendő beosztáshoz kapcsolódó, úgynevezett kategóriafeltételek kerülnek ellenőrzésre. Ezen feltételek együttes teljesülésének eredményeként kerül megállapításra az egyén alkalmassága vagy hiányossága esetén az alkalmatlansága.

Ezt követi az alkalmasságvizsgálat második lépcsőjeként az úgynevezett illeszkedésvizsgálat, melynek során annak komplex felmérése történik meg, hogy az egyén képesség- és kompetenciaprofilja milyen mértékben illeszkedik a vizsgált beosztás(ok) elvárásaihoz. Ennek eredményeként egyrészt világosan megállapítható, hogy a vizsgált egyén számára a képességei és kompetenciái alapján mely szakterület, illetve beosztás betöltése lenne a legmegfelelöbb, másrészt pedig - éppen ezen eredményekre alapozva - sorrend alakítható ki a rendvédelmi szervekhez, illetve képző intézményekbe felvételre jelentkező, vagy később az egy adott beosztásra pályázók között. A KLIR rendszer kétlépcsős alkalmasságvizsgálata így egyszerre több szinten képes felmérni az egyén és a munka illeszkedését, ezzel is támogatva az egyén jövőbeni beválását, ezen keresztül pedig a szervezeti hatékonyságot.

\section{Rugalmasság a központi elvárásokkal szemben}

Jelenkorunk talán egyik legjellemzőbb vonása tágabb és szükebb világunk folyamatos és egyre gyorsuló változása, melyhez való alkalmazkodás képessége az egyén sikeres túlélésének záloga. Az egyéneken túl a munkahelyi szervezetek fennmaradásához, müködési hatékonyságuk megőrzéséhez is elengedhetetlen, hogy flexibilisek legyenek mind a szervezeti felépítésük, mind a vezetési módszereik, mind pedig az alkalmazottaik képességeit, kompetenciáit illetően. A kutatók és a gyakorlati szakemberek egyetértenek abban, hogy egy munkahelyi szervezet sikeres jövője szempontjából a változásokra való hatékony reagálás érdekében a szervezet rugalmassága, valamint a dolgozók kompetenciafejlesztése alapvető fontosságú. Megjegyzendő, hogy a szervezeti rugalmasság sokkal inkább a szervezet szemléletében és múködésében, mint annak szervezeti struktúrájában vagy épp vezetési stílusában érhető tetten. A szervezet azon képességét jelzi ugyanis, hogy tevékenységét képes az aktuális helyzethez 
- külső és belső körülményekhez - igazítani, az eredményesség érdekében akár vezetési módszert, szervezeti struktúrát, kompetenciafejlesztési irányokat váltani, módosítani. A rugalmas szervezet a változás szükségességét folyamatosnak tekinti, melynek során újra és újra megújulásra törekszik. Hangsúlyozandó, hogy az igazán hatékony változás egyszerre érinti a keretet adó struktúrát, az emberi viselkedést, valamint a szervezeti kultúrát (Kaucsek \& Simon, 2002).

A rugalmasság jelentős szerepe a munka egészségre gyakorolt hatásában is tetten érhető. Jól példázza ezt a WHO munkahelyi stresszel kapcsolatos kutatásainak kiindulási alapjaként szolgáló, Karasek (Karasek \& Theorell, 1990) nevéhez füződő Job demand - Control - Support (Megterhelés - Kontroll - Támogatás) modell, amely a munkahelyi stressz kapcsán a munka okozta megterhelés mellett, annak hatását moderáló tényezőként az egyén munkája felett gyakorolt kontrolljának mértékét hangsúlyozza. Amennyiben az egyénnek lehetősége van arra, hogy beleszóljon az általa végzendő munka folyamatába (válthat az egyes munkakörök között, meghatározhatja a végzendő munka menetét, részcéljait, időbeosztását, eszközeit stb.), akkor még az olyan bizonyítottan magas megterhelést jelentő munka esetében is, mint a rendvédelmi munka, elérhető, hogy a munkahelyi stressz az egyén fejlődésének a forrása, ne pedig a megbetegítő tényezöje legyen (Szabó \& Rigó, 2005; Szabó, 2009).

A rugalmasság fontosságát a piaci szféra mellett a magyar állami szervek is felismerték. Ezt jelzi a 2010-ben megkezdett, Magyary Zoltán nevével fémjelzett közigazgatásfejlesztési program alapfilozófiája is, mely szerint ,,az egyre összetettebb és egyre gyorsabban változó társadalmi és gazdasági kihivások stratégiai rugalmasságot, illetve olyan képességeket igényelnek, amelyek alkalmassá teszik az államszervezetet a kockázatok kezelésére és a versenyképesség javitására, miközben az alapjogok biztositása és az állami alapfeladatok ellátása sem szorul háttérbe” (Bokodi, Fekete, Lóczy \& Szakács, 2020). A mindezzel összefüggő főbb stratégiai célkitüzések közül - a közszolgálat szolgáltató szemléletének erősítése érdekében - kiemelendő az emberierőforrás-gazdálkodás fejlesztése. Ezt a célt szolgája a Belügyminisztérium és a Nemzeti Közszolgálati Egyetem konzorciumi partnerségében, a Belügyminisztérium irányításával megvalósuló „A versenyképes közszolgálat személyzeti utánpótlásának stratégiai támogatása" elnevezésü, KÖFOP-2.1.5VEKOP-16-2016-00001. azonosító számú projekt (a továbbiakban: Projekt), melynek keretében megújult a rendvédelmi szervek hivatásos állománya számára kötelező alkalmasságvizsgálati rendszer, és megszületett a Kétlépcsős Integrált Alkalmasságvizsgálati Rendszer.

A KLIR rendszer, hủen az ôt életre hívó Projekt szellemiségéhez és alapvető célkitüzéseihez, egyik fő jellemzője a rendvédelmi szervek előtt álló, 
a humánerőforrás-gazdálkodást - azon belül is elsősorban az állomány kiválasztását és képzését - érintő aktuális kihívásokra való rugalmas reagálóképesség.

A rugalmas döntéshozás és egyben a vezetôi autonómia egyértelmű jeleként értelmezhető a KLIR rendszer azon jellemzője, hogy az első lépcsőben megvizsgált minimum- és kategóriafeltételek teljesülését követően a kinevezésre jogosult vezetőre bízza, hogy az illeszkedésvizsgálatok eredményeit milyen módon hasznosítja, illetve építi be a konkrét személyzeti döntésébe. Erre utal az integrált kifejezés a KLIR megnevezésében, mely jelzi, hogy az alkalmasságvizsgálatok összegzett eredményei mellett a sikeres vezetői döntés meghozatalához elengedhetetlen minden olyan információ integrált figyelembevétele, melyek relevánsnak tekinthetők a kiválasztás szempontjából (például végzettség, szakmai tapasztalat, szilárd erkölcsiség stb.). Ezen vezetöi döntéssel kapcsolatban a Rendelet semmilyen további megkötést nem tartalmaz, az illeszkedésvizsgálat eredményeként kialakuló sorrendet vezetői döntést támogató információnak tekinti. Annyit ír pusztán elő, hogy a Hszt. szerinti vezetői besorolású beosztások esetén a kinevezésre jogosult vezető a szolgálati elöljárója felé indokolni köteles, amennyiben döntése eltér a sorrend alapján javasolt személytől.

Az alkalmasságvizsgálati követelményeknek az aktuális elvárásokhoz való rugalmas igazodását teszi lehetővé a KLIR rendszer azon alapelve is, miszerint az alkalmasságvizsgálat mindig a betöltendő vagy a betöltött beosztáshoz igazodik. Ennek megvalósítása érdekében kialakításra került a szolgálati beosztások új alkalmasságvizsgálati kategóriarendszere, melynek lényege, hogy az egyes beosztásokat az általuk okozott egészségi, pszichológiai és fizikai megterhelés alapján 12 különböző kategóriába sorolja a 1. számú táblázatban szerepeltek szerint.

1. számú táblázat: $A$ KLIR rendszer alkalmasságvizsgálati kategóriái

\begin{tabular}{|c|c|c|c|c|c|c|}
\hline \multicolumn{3}{|c|}{ Alkalmasságvizsgálati kategóriák: } & Beosztott & Irányító & Vezetö & Fizikai terhelés \\
\hline \multirow{4}{*}{ 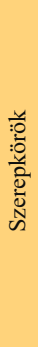 } & $\begin{array}{l}\text { Nem alapfelada- } \\
\text { tot végez }\end{array}$ & Támogató & I. & V. & IX. & $\begin{array}{c}\text { könnyü/ } \\
\text { közepes } \\
\text { (irodai munka) }\end{array}$ \\
\hline & \multirow{3}{*}{$\begin{array}{l}\text { A rendvédelmi } \\
\text { szerv alapfelada- } \\
\text { tát végzi }\end{array}$} & $\begin{array}{l}\text { Adminisztratív/ } \\
\text { hatósági }\end{array}$ & II. & VI. & $\mathrm{X}$. & $\begin{array}{c}\text { könnyü/ } \\
\text { közepes } \\
\text { (fóként irodai) }\end{array}$ \\
\hline & & $\begin{array}{l}\text { Beavatkozó/ } \\
\text { intézkedő }\end{array}$ & III. & VII. & XI. & $\begin{array}{c}\text { fokozott } \\
\text { (föként terepen) }\end{array}$ \\
\hline & & Speciális & IV. & VIII. & XII. & $\begin{array}{l}\text { kiemelten } \\
\text { fokozott }\end{array}$ \\
\hline \multirow{2}{*}{\multicolumn{3}{|c|}{ Pszichológiai kompetenciaelvárások }} & alap & irányítói & vezetői & \\
\hline & & & \multicolumn{3}{|l|}{ kompetenciák } & \\
\hline
\end{tabular}

Forrás: A szerzők saját szerkesztése. 
A táblázatban jól nyomon követhetők az egyes alkalmasságvizsgálati kategóriák főbb jellemzői. Látható, hogy a kategóriarendszer egyrészt azt vizsgálja, hogy az adott beosztás a Hszt. szerint beosztotti vagy vezetôi beosztásnak minősül-e. Elismerve azt a tényt, hogy számos olyan beosztás létezik a rendvédelmi szerveknél, melyek bár nem minősülnek vezetői besorolású beosztásnak, mégis más emberek munkájának szervezésével, irányításával és ellenőrzésével járnak, így fokozott megterhelést jelentenek ezen beosztásokat betöltők számára, bevezetésre került az irányítói beosztás kategóriája. Ezen beosztáskategória tipikus példája az alosztályvezető, a csoportvezető, a szolgálatparancsnok, akik által végzett mindennapi tevékenység során egyértelmüen megjelennek a vezetői szerepből, valamint annak más szerepekkel való konfliktusából eredő feszültségek (Malét-Szabó, 2020b), melyek hatékony kezelésére való képesség alapvető feltétele ezen beosztáskategóriába tartozó beosztás sikeres betöltésének.

Az új kategóriarendszer mindezeken túl figyelembe veszi, hogy az adott beosztás a rendvédelmi szerv alapfeladatának az ellátását szolgálja-e. Amennyiben igen, úgy további szempontként az adott beosztás által okozott fizikai megterhelés (balesetveszélyesség) mértéke szerepel. Ezen szempont szerint négy különböző szerepkört határoz meg a Rendelet: a támogató, az adminisztratív/ hatósági, a beavatkozó/intézkedő és a speciális szerepkört.

Az I. alkalmasságvizsgálati kategória kiemelt szereppel bír, mivel ez az egyetlen olyan kategória, mellyel kapcsolatos alkalmasságvizsgálati elvárások - az úgynevezett minimumfeltételek - a teljes rendvédelmi hivatásos állomány vonatkozásában egységesnek tekinthetők. Az összes többi alkalmasságvizsgálati kategória esetében kötelezően teljesítendő alkalmasságvizsgálati követelményeket hívjuk kategóriafeltételeknek, melyekkel szemben a Rendelet pusztán azt az elvárást fogalmazza meg, hogy nem lehetnek enyhébbek, mint a minimumfeltételek.

A KLIR rendszer egyik igen fontos vívmánya, hogy a rugalmasság magába a szabályozási rendszerbe is beépítésre került. A régi szabályozási rend a Hszt. vonatkozó elvárásainak való megfelelés érdekében részletes - számos igen terjedelmes melléklettel rendelkező - miniszteri rendeletben szabályozta a rendvédelmi szervek hivatásos állománya számára kötelező alkalmasságvizsgálati rendszer minden egyes teljesítendő egészségi, pszichológiai és fizikai kritériumát, mely utóbbi esetében még a végrehajtandó gyakorlatok pontos leírását is szerepeltette. A rendvédelmi szervek alkalmasságvizsgálati gyakorlatában egyedül az általuk elkészített különbözö szakmai protokollok biztosítottak lehetőséget a saját specifikus elvárásaikhoz való igazodásra, mely a pszichológiai alkalmasságvizsgálatok egységes kritériumainak eltérő vizsgálati módszertanában volt leginkább tetten érhető. A Rendeletben szereplő elvárásoktól való, 
mindezen túlmutató eltérésre a rendvédelmi szerveknek nem volt lehetősége. Ez a hosszú ideig fennálló gyakorlat egyértelmüen igazolta, hogy ez a fajta szabályozási rend nem teszi lehetôvé az olyan változó elvárásokra való gyors reagálást, mint például egy újonnan jelentkező szakmai feladat végrehajtása érdekében való új beosztás kialakítása, valamint az ahhoz kapcsolódó alkalmassági feltételek meghatározása.

A rendvédelmi szervek rugalmas reagálóképességének elősegítése érdekében és egyben támogatva a szervek vezetőinek autonómiáját az alkalmasságvizsgálatok szabályozási rendjébe - a Hszt. 106/A. § alapján meghatározottak szerint - beépítésre került egy új szint, a rendvédelmi szerv vezetője (a belügyminiszter irányítása alá tartozó rendvédelmi feladatokat ellátó szerv országos föigazgatója vagy országos parancsnoka) által kiadott közjogi szervezetszabályozó eszköz. Az új szabályozási rendben a miniszteri Rendelet az alkalmasságvizsgálatok általános strukturális szabályait (az alkalmasságvizsgálati kategóriákat, az alkalmasságvizsgálatok típusait, minősítéseit, érvényességét, időbeli rendjét, a jogorvoslati lehetőségeket, valamint az alkalmasságvizsgálatokat végzőkkel szembeni elvárásokat), valamint a rendvédelmi szervek minden hivatásos állományú kollégájára egyaránt érvényes egészségi, pszichológiai és fizikai minimumfeltételeket határozza meg. Az ezen túlmutató, a különböző alkalmasságvizsgálati kategóriákba tartozó beosztásokkal szembeni elvárásokat, valamint az egyes beosztások alkalmasságvizsgálati kategóriákba való besorolását maga a rendvédelmi szerv vezetője határozhatja meg közjogi szervezetszabályozó eszközben, az egyes alkalmasságvizsgálatot végző szakemberek konkrét kijelölésével együtt. Mindehhez kapcsolódóan arra is van lehetősége, hogy a Rendeletben meghatározott alkalmasságvizsgálati kategóriákon belül bizonyos beosztásokkal szemben további alkalmasságvizsgálati feltételeket is elöírjon. Az egyes rendvédelmi szervek, illetve specifikus beosztások elvárásaihoz való rugalmas igazodást segíti elő a rendvédelmi szerv vezetöjének azon jogköre is, miszerint a Rendelet keretei között maga határozhatja meg az úgynevezett időszakos alkalmasságvizsgálatok gyakoriságát, melynek célja az állomány aktuális alkalmassági állapotának rendszeres időközönként történő monitorozása.

Összességében elmondható, hogy az új háromszintű szabályozási rend eredményeként a rendvédelmi szervek vezetőinek közvetlen lehetősége van arra, hogy az alkalmasságvizsgálati követelményeiket a saját specifikus feladataikhoz igazodva határozzák meg, illetve azt közvetlenül módosítsák amennyiben változnak az elvárások. Ilyen fokú szabadságra és önállóságra az alkalmasságvizsgálatok kapcsán soha nem volt még lehetősége a rendvédelmi szerveknek. A Rendelethez kapcsolódóan kiadott közjogi szervezetszabályozó eszközökben tetten érhető igen szerteágazó követelményrendszer, valamint az alkalmasságvizsgálati 
szakmai protokollokban megjelenő sokszínű vizsgálati módszertanok egyértelmüen alátámasztják mindennek az aktualitását és létjogosultságát.

2. számú táblázat: $A$ KLIR szabályozási rendszere

\begin{tabular}{|c|c|c|c|}
\hline $\begin{array}{l}\text { Az alkalmasságvizsgála- } \\
\text { tok jellemzöi }\end{array}$ & $\begin{array}{l}\text { 45/2020. (XII.16.) } \\
\text { BM rendelet }\end{array}$ & $\begin{array}{c}\text { Közjogi szervezetszabályo- } \\
\text { zó eszközök }\end{array}$ & $\begin{array}{l}\text { Alkalmasságvizsgálati } \\
\text { szakmai protokollok }\end{array}$ \\
\hline $\begin{array}{c}\text { Az alkalmasságvizsgála- } \\
\text { tok típusai }\end{array}$ & $\begin{array}{l}\text { A típusok meghatá- } \\
\text { rozása }\end{array}$ & & \\
\hline $\begin{array}{c}\text { Alkalmasságvizsgálati } \\
\text { kategóriák }\end{array}$ & $\begin{array}{l}\text { A kategóriák megha- } \\
\text { tározása }\end{array}$ & $\begin{array}{c}\text { A beosztások kategóriákba } \\
\text { sorolása }\end{array}$ & \\
\hline $\begin{array}{l}\text { Alkalmasságvizsgálatot } \\
\text { végző szakemberek }\end{array}$ & $\begin{array}{l}\text { A szakemberekkel } \\
\text { szembeni elvárások }\end{array}$ & A szakemberek kijelölése & \\
\hline $\begin{array}{c}\text { Alkalmasságvizsgálatok } \\
\text { gyakorisága }\end{array}$ & $\begin{array}{l}\text { Keretszabályok } \\
\text { meghatározása }\end{array}$ & $\begin{array}{l}\text { A pontos gyakoriságok } \\
\text { meghatározása }\end{array}$ & \\
\hline $\begin{array}{c}\text { Alkalmasságvizsgálati } \\
\text { dokumentumok }\end{array}$ & $\begin{array}{l}\text { Adattartalom, adatke- } \\
\text { zelési szabályok; }\end{array}$ & Mintadokumentumok & \\
\hline $\begin{array}{c}\text { Alkalmasságvizsgálati } \\
\text { követelmények }\end{array}$ & $\begin{array}{l}\text { Minimumfeltételek } \\
\text { meghatározása }\end{array}$ & $\begin{array}{l}\text { Kategóriafeltételek megha- } \\
\text { tározása }\end{array}$ & $\begin{array}{l}\text { Az egyes alkalmassági } \\
\text { feltételek vizsgálati } \\
\text { módszertana }\end{array}$ \\
\hline Prevenciós kérdöiv & $\begin{array}{l}\text { Alkalmazásának } \\
\text { rendje }\end{array}$ & & A kérdöív tartalma \\
\hline Illeszkedésvizsgálatok & $\begin{array}{l}\text { Végzésük rendje; a } \\
\text { kötelezö pszichológi- } \\
\text { ai kompetenciák }\end{array}$ & $\begin{array}{l}\text { Eredményeinek felhasználá- } \\
\text { sára vonatkozó eljárásrend }\end{array}$ & $\begin{array}{l}\text { Az illeszkedésvizsgálatok } \\
\text { módszertana (mérési, sor- } \\
\text { rendállítási gyakorlat) }\end{array}$ \\
\hline
\end{tabular}

Forrás: A szerző saját szerkesztése.

\section{Tudományos kutatás mint a vizsgálati módszertan megalapozása}

A KLIR rendszer egyik felvállalt célja annak rendszerszintü képviselete, hogy az alkalmasságvizsgálatok során alkalmazott vizsgálati módszertanok tudományos kutatások eredményeit felhasználva kerüljenek kialakításra.

Ennek első bizonyítékaként tekinthető, hogy a KLIR rendszer már struktúrájában is a szakmai tisztaságot képviseli. A korábbi gyakorlat az alkalmatlanná válás szempontjából az egészségi alkalmasságvizsgálatot a másik két alkalmasságvizsgálat fölé helyezte azzal, hogy pszichológiai és fizikai alkalmatlanság esetén is az egészségi felülvizsgálati eljárástól tette függővé az egyén további foglalkoztatását. A KLIR rendszerben ettől jelentősen eltérően az egyes szakterületek - azaz az egészségi, pszichológiai és fizikai alkalmasságvizsgálatok - már élesen elkülönülnek egymástól. Igaz ez mind szakmailag, mind pedig az 
eljárás szempontjából első- és másodfokon, valamint a Rendelet által a soron kívüli, illetve ismételt alkalmasságvizsgálat során másodfokon született alkalmatlan minősítést követően bevezetett, úgynevezett bizottsági szinten is. Alkalmatlanság miatt a hivatásos állományú kollégának a Hszt. 86. § (2) bekezdés a) pontja alapján történő szolgálati beosztásából való felmentésére kizárólag a FÜV bizottság, illetve legalább két rendvédelmi szerv tapasztalt szakembereiből álló háromfős pszichológiai vagy fizikai bizottság által hozott alkalmatlan minősítést követően kerülhet sor. Így minden hivatásos állományú kolléga esetében biztosított, hogy alkalmasságát legalább három körben vizsgálják és minősítsék egyre tapasztaltabb szakemberek mielőtt alkalmatlanság miatt felmentenék szolgálati beosztásából.

A tudományos igényesség leglátványosabb megnyilvánulása a KLIR rendszerben a kötelező érvénnyel bevezetett, a hatékony munkavégzéshez elengedhetetlen személyiségjellemzőket, képességeket és készségeket összefoglaló pszichológiai kompetenciák rendszere és vizsgálati módszertana, mely teljes egészében tudományos kutatások eredményei alapján került kialakításra. Ennek részletes ismertetése található meg Malét-Szabó és a Debreceni Egyetem kutatóinak (2021b) tanulmányában, mely lépésről lépésre vezet végig a KLIR alkalmasságvizsgálati kategóriarendszerének egyik tengelyét jelentő alap, irányítói és vezetői kompetenciák meghatározását célzó kutatásokon, a komplex mérésük érdekében kidolgozott interaktív tesztrendszerek és vizsgálati módszertanok kialakításán, felhasználva a standard nine értékelési rendszerben, valamint a neurális modellekben rejlö, az alkalmasságvizsgálati döntést támogató lehetőségeket.

A tudományos igényesség, valamint a KLIR rendszer által a rendvédelmi szervek számára a kategóriafeltételek vonatkozásában biztosított autonómia mellett az egységes szemléletmód képviselete érdekében a Rendelet létrehozta a belügyminiszter alkalmasságvizsgálatokkal kapcsolatos szakmai tanácsadó testületét a rendvédelmi szervek által delegált vezető szakemberekből. A tanácsadó testület legfontosabb feladata a rendvédelmi szervek alkalmasságvizsgálati szakmai protokolljainak véleményezése, mely nélkül ezek nem kerülhetnek kiadásra és gyakorlati alkalmazásra.

A tudományos kutatások szellemiségét követve, a korábbi alkalmasságvizsgálatok adatait felhasználva és elemezve, a rendvédelmi szervek vezető szakembereinek bevonásával kerültek meghatározásra a KLIR rendszer egységes minimumfeltételei. Ennek következményeként a korábbi vonatkozó szabályozáshoz képest az egészségi minimumfeltételek - figyelembe véve az orvostudomány fejlődését és egyes betegségek kezelhetőségének jelentős javulását - számos ponton enyhültek. Példaképpen említendő az oktatási-képzési 
intézményekbe felvételizők alkalmatlansági okai között első helyén álló látászavar (2018-ban a rendészeti szakgimnáziumokba felvételizők között az egészségügyileg alkalmatlan minősítés 30\%-áért volt felelős, míg a Nemzeti Közszolgálati Egyetemre felvételizőknél ez a szám $42 \%$ volt). A korábbi rendelet szerint már 2-2,5D esetén alkalmatlan minösítést kellett megállapítani, a KLIR-ben szereplő minimumfeltételekben viszont már - figyelemmel a látásjavító eszközök rohamos fejlődésére, valamint a különböző beosztásokra vonatkozó elvárások változására - felvételkor a +4,0D-nál és -4,0D-nál, állományban lévő kolléga esetén pedig a +6,0 D-nál és -6,0 D-nál erősebb szemüvegviselés a hivatásos szolgálatra való alkalmasság kizáró oka. A gyakorlatiasság és a rohamosan fejlődő egészségügyi ellátás eredményeinek beépítéseként enyhülhettek a szív- és érrendszeri, légzőszervi (például allergiás), valamint az endokrin megbetegedésekkel kapcsolatos feltételek, melyek szerint az enyhe fokú, terápiát nem igénylő vagy terápiára jól reagáló elváltozások (egyes ritmuszavarok, vérnyomásemelkedés) az új koncepció alapján már nem jelentenek automatikusan alkalmatlanságot. Ugyanez igaz a több, mint öt évvel ezelött, akár gyermekkorban lezajlott rosszindulatú elváltozásokra is, melyek mütéti vagy egyéb úton megszüntetésre kerültek, és a szakmai protokollok alapján a gyógyult állapot megállapítást nyert.

A pszichológiai minimumfeltételek megfogalmazása a korábbi rendeletben szereplő negatív megfogalmazással (azaz kifejezetten a kontraindikációk megjelenítésével) szereplő követelmények jelentős átgondolásával, valamint a fejleszthetőség koncepcióját szem előtt tartva a pozitívumok, azaz az elengedhetetlenül szükséges készségek és képességek megjelenítésével történt, mely az 3. számú ábrán látható letisztult követelményrendszer kialakítását eredményezte: 
3. számú ábra: A KLIR rendszer pszichológiai minimumfeltételei

\begin{tabular}{|c|c|c|c|}
\hline \multicolumn{2}{|r|}{$\begin{array}{l}\text { Pszichológiai kontraindikációk, kizáró tényezők } \\
\text { megnevezése } \\
\text { 57/2009. IRM-ÖM-PTNM rendelet }\end{array}$} & \multicolumn{2}{|r|}{$\begin{array}{c}\begin{array}{c}\text { Általános pszichológiai } \\
\text { minimumfeltételek }\end{array} \\
45 / 2020 . \text { (XII.16.) BM rendelet }\end{array}$} \\
\hline \multicolumn{2}{|r|}{ 1. Személyiségbeli tényezők } & \multicolumn{2}{|r|}{ 1. A személyiség egészével kapcsolatos elvárások } \\
\hline 1.1 & Pszichés egyensúly tartós hiánya & 1.1 & Kiegyensúlyozott pszichés állapot \\
\hline 1.3 & $\begin{array}{l}\text { A személyiség érettségének nem megfelelö } \\
\text { szintje }\end{array}$ & \multirow{2}{*}{1.2} & \multirow[t]{2}{*}{ Életkornak megfelelő érettség } \\
\hline 1.11 & Önértékelés tartós zavara & & \\
\hline 1.5 & $\begin{array}{l}\text { Túlzott szorongásra, vagy a szorongás hiányá- } \\
\text { ra utolsó személyiségjegyek }\end{array}$ & \multirow[b]{3}{*}{1.3} & \multirow[b]{3}{*}{$\underline{\text { Átlag feletti érzelmi-indulati kontroll }}$} \\
\hline 1.6 & Pszichoszomatikus tünetképződés & & \\
\hline 1.7 & $\begin{array}{l}\text { Önkontroll hiánya, zavara, túlzott agresszivi- } \\
\text { tásra (auto-, heteroagresszió) utaló személyi- } \\
\text { ségjegyek, emocionális kontroll nem megfelelő } \\
\text { szintje }\end{array}$ & & \\
\hline 1.9 & $\begin{array}{l}\text { Pszichés terhelhetőség, stresszel való megküz- } \\
\text { dés (frusztrációs tolerancia) alacsony szintje }\end{array}$ & 1.4 & $\begin{array}{l}\text { Átlagos pszichés terhelhetőség, stresszel való } \\
\text { megküzdési képesség }\end{array}$ \\
\hline 1.4 & $\begin{array}{l}\text { Szociabilitás nem megfelelő szintje, túlzott } \\
\text { introverzió, túlzott extraverzió }\end{array}$ & \multirow{2}{*}{1.5} & \multirow{2}{*}{ Átlagos alkalmazkodási képesség } \\
\hline 1.10 & $\begin{array}{l}\text { Alkalmazkodási készség, flexibilitás alacsony } \\
\text { szintje }\end{array}$ & & \\
\hline & & \multicolumn{2}{|r|}{ 2. Kognitív képességekkel kapcsolatos elvárások } \\
\hline \multicolumn{2}{|c|}{$\begin{array}{l}\text { 2. Intellektuális képességek nem megfelelő szintje, } \\
\text { zavara }\end{array}$} & 2.1 & Átlagos intellektuális képességek \\
\hline \multicolumn{2}{|c|}{$\begin{array}{l}\text { 3. Figyelmi, szenzomotoros képességek nem megfelelő } \\
\text { szintje, tartós zavara }\end{array}$} & 2.2 & Átlagos figyelmi, szenzomotoros képességek \\
\hline 7. & Alacsony fokú pálya-, illetve munkamotiváció & 2.4 & Átlagos teljesítménymotiváció \\
\hline \multirow{3}{*}{\multicolumn{2}{|c|}{$\begin{array}{l}\text { 4. Kommunikációs készségek nem megfelelő szintje, } \\
\text { zavara }\end{array}$}} & \multicolumn{2}{|r|}{ 3. Társas készségekkel kapcsolatos elvárások } \\
\hline & & 3.1 . & $\begin{array}{l}\text { Átlagos szóbeli kommunikációs készségek } \\
\text { (beszédzavar, beszédhiba nélküli) }\end{array}$ \\
\hline & & 3.2 . & Átlagos írásbeli kommunikációs készségek \\
\hline & & & Társadalmi normáknak való megfelelés: \\
\hline 1.8 & Felelősségtudat nem megfelelő szintje & 4.1 & Átlagos felelösségtudat \\
\hline $\begin{array}{l}\text { 6. Ért } \\
\text { vel ve }\end{array}$ & $\begin{array}{l}\text { ékelhetetlen teszteredmények, vizsgálatvezető- } \\
\text { ló nem megfelelő együttmüködés, a vizsgálat } \\
\text { szabályainak megszegése }\end{array}$ & 4.2 & $\begin{array}{l}\text { Szabálykövetö, fegyelmezett magatartás, mely- } \\
\text { nek keretében elvárt a vizsgálatok során való } \\
\text { együttmüködés, azok szabályainak a betartása, a } \\
\text { tesztek értékelhetö kitöltése }\end{array}$ \\
\hline 5.1 & Viselkedési addikciók & 4.3 & $\begin{array}{l}\text { Élettörténete mentes a kóros függőségektől } \\
\text { (például játékszenvedély, alkoholfüggőség, } \\
\text { drogfüggőség stb.) }\end{array}$ \\
\hline 5.2 & $\begin{array}{l}\text { Szuicid cselekmények, „kísérlet” vagy ráutaló } \\
\text { magatartás }\end{array}$ & 4.4 & $\begin{array}{l}\text { Élettörténete mentes öngyilkossági kísérlettöl, } \\
\text { öngyilkosságra utaló magatartástól }\end{array}$ \\
\hline
\end{tabular}

Forrás: A szerző saját szerkesztése.

\section{A fizikai minimumfeltételek esetében élesen elválnak egymástól a rendvé- delmi oktatási intézményekbe felvételt megelőzően teljesítendő képzési}


minimumfeltételek és a hivatásos állomány betöltésének általános minimumfeltételei. Az előbbiek kapcsán végrehajtandó „Három gyakorlat módszere” (20 méteres ingafutás, falra dobás medicinlabdával, átugrás zsámoly felett hason fekvésbe) a keringési rendszer terhelhetőségének, illetve a láb- és a felsőtest erő-állóképességének mérésén keresztül a rendészeti munkához leginkább szükséges izomcsoportok, és a kardiovaszkuláris rendszer terhelhetőségét és egyben fejleszthetőségét vizsgálja elsősorban, előkészítve az oktatási intézményektől elvárt fejlesztési folyamatot. A hivatásos állományban lévő kollégákra vonatkozó minimumfeltételek pedig - igazodva az állomány körében jelentkező különböző egészségügyi problémákhoz - a végrehajtandó gyakorlatok szintjén választhatóvá váltak (négyféle Cooper-teszt közül választhatnak a kollégák: 12 perc folyamatos futás, úszás, kerékpározás vagy evezőpad közül).

A rendvédelmi szervek által meghatározott kategóriafeltételek vonatkozásában, megfelelve a Rendelet vonatkozó rendelkezéseinek, szintén alapvető elvárás volt a tudományos megalapozottság. Természetesen mivel az új alkalmasságvizsgálati rendszer - különösen a fizikai alkalmasságvizsgálatok esetében - számos új vizsgálati módszertant is tartalmaz, melyekre vonatkozóan korábbi tapasztalati adatokkal a rendvédelmi szervek nem rendelkeztek, így a kapcsolódó kritériumértékek ezekben az esetekben első körben csak a hazai, illetve nemzetközi sztenderdek alapján kerülhettek kialakításra. Éppen ezért a tanácsadó testület az alkalmasságvizsgálati szakmai protokollok kapcsán egyéves türelmi időt követően, azaz 2021 végén, az egy év alatt összegyült alkalmasságvizsgálati adatok elemzését, ennek eredményei alapján pedig a kategóriafeltételek újrakalibrálását javasolta.

\section{A fejlesztés lehetősége a statikussággal szemben}

Ahogy azt a fentiekben már tárgyaltuk a változó világhoz való sikeres alkalmazkodás egyik kulcsa - a rugalmasság mellett - a dolgozók folyamatos fejlesztésének biztosítása, mely a szervezeti szocializációban is igen fontos szerepet játszik. Mindezt, valamint azt a tényt felismerve, miszerint folyamatosan csökken a rendvédelmi szervekhez jelentkezők létszáma, a KLIR rendszer egyik fontos alapelve lett a támogatás és fejleszthetőség, mely magában foglalja az egészségfejlesztést és egészségmegőrzést célzó tevékenységeket, a hivatásos állomány tagjainak mentálhigiénés támogatását, a kötelező egyéni továbbképzési rendszer keretében a kompetenciák fejlesztését, valamint a fizikai erőnléti állapot fenntartását célzó törekvéseket egyaránt. Az egészségfejlesztési törekvések részeként került bevezetésre a prevenciós kérdőív, mely egyaránt 
támogatni hivatott az orvosok és a pszichológusok munkáját. A kérdőív egyrészt lehetőséget ad a szakemberek számára a vizsgálaton részt vevő kolléga aktuális egészségtudatos magatartásának feltérképezésére, másrészt összegzése hasznos információkat szolgáltat az állomány egészét érintő egészségfejlesztési törekvések megtervezéséhez és megvalósításához.

A tudatos fejlesztést szolgálja még az egyén fejlesztendő pszichológiai kompetenciáinak becsatornázása a kötelező egyéni továbbképzési rendszerbe, melynek érdekében közvetlen kapcsolat került kialakításra a KLIR rendszert támogató KOMP (Komplex Kompetenciaalapú Kiválasztási és Képzési Rendszer) informatikai rendszer, valamint a rendvédelmi hivatásos állomány kötelező egyéni továbbképzési rendszerét támogató RVTV portál között. Ennek eredményeként a kötelező egyéni továbbképzési rendszer képessé vált arra, hogy az egyén egyedi fejlesztési igényeihez igazodó képzéseket ajánljon fel, mely az egyén életpályájának tudatos támogatását szolgálja. A szervezeti hatékonyság támogatása mellett ezt a célt szolgálja a KLIR rendszer azon újítása is, miszerint az illeszkedésvizsgálatok részeként végrehajtott kompetenciavizsgálatok eredményeit az állományilletékes parancsnok kérésre megismerheti, személyzeti döntéséhez felhasználhatja.

A kiválasztás és a képzés szerves összekapcsolódásának egyik szemléletes példájaként tekinthető, hogy már a KLIR rendszer kompetenciaalapú mérési módszertanát (Malét-Szabó et al., 2021b) megalapozó Komplett Vezetőkiválasztási Rendszer (röviden: KVR) kialakításával párhuzamosan megjelent annak az igénye, hogy a kiválasztási rendszer és a belügyi rendvédelmi szervek állománya körében a vezetővé válás kötelező elemeként szereplő vezetőképzés között élő és közvetlen kapcsolat kerüljön kialakításra. Ezt az igényt szem előtt tartva a vezetővé képző tréningek módszertana - a KVR eljárás bevezetését követően - átalakításra került, melynek során az egyes vezetői kompetenciákat pontosan lekövetve modulrendszerü tréning módszertanok kerültek kialakításra e-learning támogatással (azaz a blended-learning komplex módszertanát felhasználva). Mindezen keresztül lehetővé vált, hogy - bizonyos kötelező elemek megtartása mellett - az adott vezetővé képző tréningcsoportba tartozó egyének fejlesztési igényeihez igazodva kerüljön kialakításra az adott tréning konkrét módszertana. Ezt elősegítendő a trénerek a tréninget megelőzően megismerhetik a csoportjukba tartozó egyének egyéni kompetenciaprofiljait, melyek ismeretében - informatikai rendszer által támogatottan - kialakíthatják az egyéni és csoportos fejlesztési terveket, és véglegesíthetik a konkrét tréning módszertanát. Az egyéni fejlődési ív nyomon követését, ezen keresztül pedig az egyéni és szervezeti tudatos HR támogatást is szolgálja, hogy a tréningek végén az értékelés is az egységes belügyi vezetöi kompetenciák mentén történik, mind a 
trénerek, mind pedig az AC jellegü vizsga esetében konkrétan számszerüsítve az egyén fejlődését az egyes vezetöi kompetenciákban. Fontos hangsúlyozni, hogy követve a standard nine értékelési rendszer koncepcióját az egyéni fejlödés értékelése nem objektív számok mentén történik, hanem az egyén és a tréner által a tréningfolyamat elején közösen meghatározott célokhoz viszonyítva, annak elérését százalékos mértékben megjelenítve (a százalékos érték azt mutatja meg, hogy az egyén milyen mértékben tudta megvalósítani a fejlesztési tervében számára előírt fejlődést). Ezzel a momentummal pedig teljessé válik a kiválasztás és a képzés egymással szorosan összefüggő, szervesen egymásra épülö rendszere úgy, hogy az egyéni, a csoportos - és akár a szervezeti szintü - fejlődés egyértelmüen mérhetővé, ezen keresztül pedig követhetővé válik minden érintett fél számára.

A fejleszthetőség lehetőségének és szükségességének biztosítását a KLIR rendszer a rendvédelmi szervek állományán túl kiterjeszti a rendvédelmi oktatási intézményekre is. Ezen intézményekbe felvételizők esetében bevezette az úgynevezett képzési minimumfeltételeket, melyek a képzés ideje alatt szakmai támogatással fejleszthető pszichológiai és fizikai kompetenciák vonatkozásában enyhébb követelményeket fogalmaznak meg, mint a hivatásos állományra vonatkozó minimumfeltételek. Mindezzel párhuzamosan kötelezővé tette a felvett hallgatók és tanulók esetében a felvételi alkalmasságvizsgálati eredményeikre épülő egyéni fejlesztési tervek készítését, és elöírta, hogy a rendvédelmi oktatási intézmény képzését úgy kell felépíteni, hogy az biztosítani tudja a felvételiző pszichológiai és fizikai kompetenciafejlesztési szükségleteit annak érdekében, hogy a képzés befejezésekor alkalmas legyen a rendvédelmi hivatásos állománytól elvárt szolgálatteljesítésre. Ez utóbbit szolgálja az egészségi képzési minimumfeltételek szigorúbb volta is, amelyek a kor előrehaladtával törvényszerüen romló egészségi állapotot figyelembe véve kerültek meghatározásra.

A kiválasztási és a képzési rendszer szerves összekapcsolódását jeleníti meg szemléletesen a 4. számú ábra, melyen lépésenként nyomon követhető az egyéni életpályát kísérő alkalmasságvizsgálatok és kompetenciafejlesztések folyamata. 
4. számú ábra: A KLIR kiválasztási és képzési rendszerének folyamata

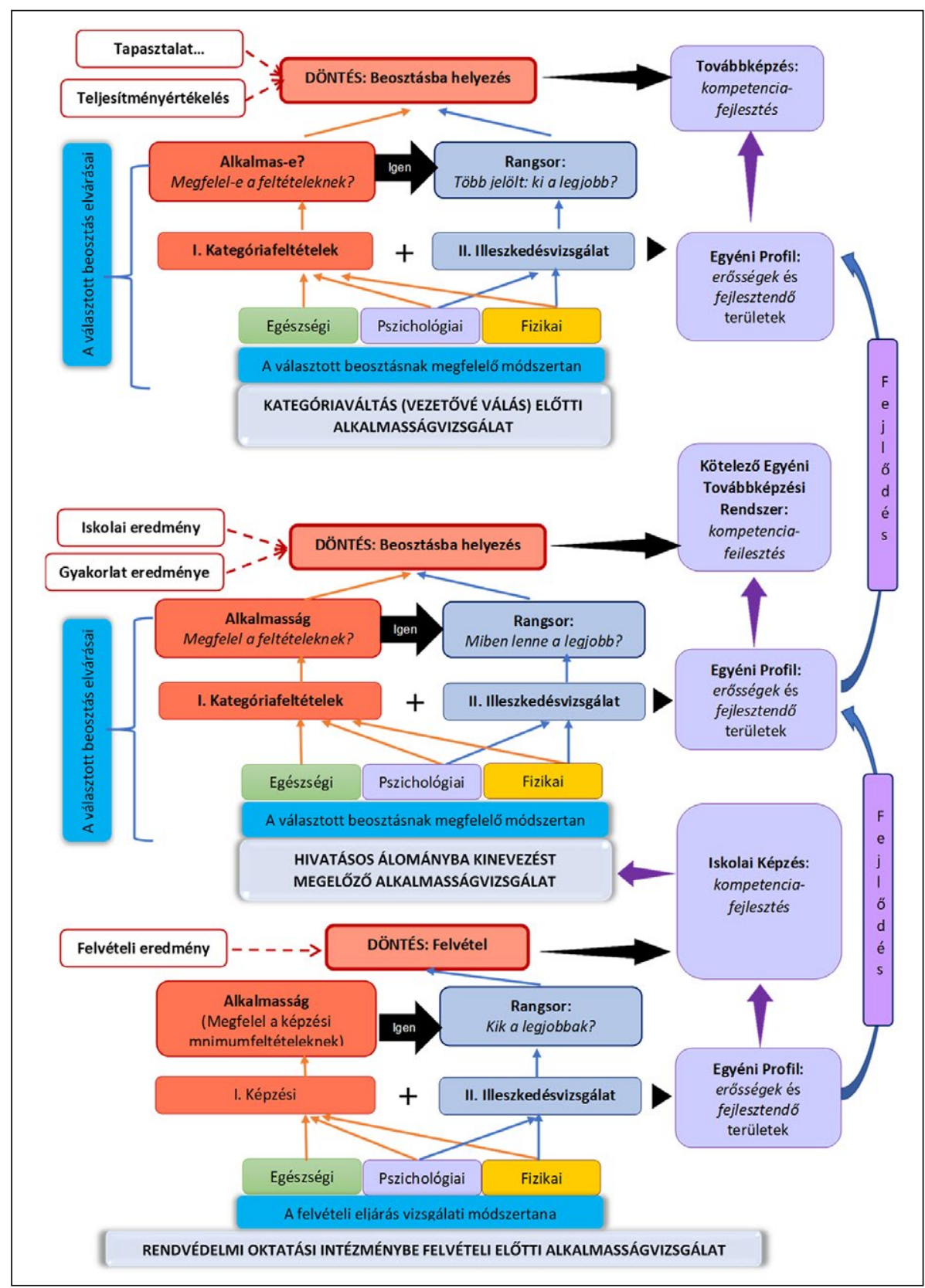

Forrás: A szerzők saját szerkesztése. 
A fentieken túl a fejlesztés fontosságára hívja fel a figyelmet, és egyben teremti meg a lehetőséget a KLIR rendszer azáltal is, hogy soron kívüli alkalmasságvizsgálat esetén - melyre elsősorban a mindennapi munkavégzés során felmerülő akut problémák kivizsgálása érdekében kerül sor - a vizsgálatot végző szakembernek lehetősége van úgynevezett ideiglenes minősítéseket adni, amennyiben úgy ítéli meg, hogy az egyén számára ennek időtartama alatt kötelezően biztosítandó támogatás, gondozás mellett 365 napon belül várható az egyén alkalmasságának a visszaszerzése. Ilyen ideiglenes minősítés a korlátozással alkalmas, mely lehetőséget ad arra, hogy az egyén a számára biztosított támogatott időszak alatt csak bizonyos korlátozással végezzen „könnyített” munkát (mint például fegyver nélkül, kategóriaváltással stb.). Amennyiben az egyén aktuális állapota ennél súlyosabb, még korlátozással sem teszi lehetővé, hogy dolgozhasson, lehetőség van ideiglenesen alkalmatlan minősítést is adni, ezáltal mentesítve az egyént a munkavégzés alól a támogatott időszak időtartamára. A támogatott időszak lejártának végén úgynevezett ismételt alkalmasságvizsgálat keretében kell meggyőződni a támogatás eredményéről, mely alapján az egyén vagy visszakerülhet eredeti beosztásába, vagy alkalmasságvizsgálati kategóriát kell váltania, vagy alkalmatlan minősítés esetén bizottsági vizsgálatára kerül sor.

\section{A jövő perspektívája}

Tanulmányunkban a 2021. január 1-jével a rendvédelmi szervek hivatásos állománya körében bevezetett új Kétlépcsős Integrált Alkalmasságvizsgálati Rendszer széles körü tudományos megalapozottságát mutattuk be röviden, melynek nyomai az új szabályozási rendben, a rendszer struktúrájában, valamint a kritériumértékek és a vizsgálati módszertanok kialakításában egyaránt tetten érhetők. Az eddigi tapasztalatok azt mutatják, hogy az érintett rendvédelmi szervek a rendszer újdonságából fakadó kezdeti nehézségeket követően sikerrel elsajátították a KLIR rendszer alkalmazási gyakorlatát, és várakozva tekintenek a KOMP informatikai rendszerben rejlő jövőbeni elemzési lehetőségek elé.

A rendszer gyakorlati alkalmazhatóságának első mérföldköve az egyéves általános alkalmazása során összegyült alkalmasságvizsgálati eredmények öszszegzett elemzése alapján a kategóriafeltételekhez kapcsolódó kritériumértékek, valamint a kompetenciamérö tesztrendszerekhez kapcsolódó neurális modellek újrakalibrálása lesz majd. Mindez tervezetten, tudományos kutatási-elemzési módszertan mentén fog megvalósulni, melyhez kiindulási alapul a Komplett Vezetőkiválasztási Rendszer esetében már alkalmazott módszertan fog szolgálni. 
Az egyéni és szervezeti hatékonyságot egyaránt szolgálni hivatott alkalmasságvizsgálati és kiválasztási rendszer esetében természetes kutatói igény a rendszer beválásvizsgálata. Az ehhez kapcsolódó módszertan jövőbeni kialakításának kiindulópontjaként tekinthető a Münnich által - a Belügyi Tudományos Tanács felkérésére - a belügyi vezetőkiválasztási rendszer beválásvizsgálata kapcsán kidolgozott módszertan (Münnich, 2017).

A kompetenciarendszerek kialakításának egyik fő oka az a tény, hogy a kompetenciák képesek egységes alapot biztosítani a kiválasztási, képzési és teljesítményértékelési rendszerek számára. A belügyi rendvédelmi szervek hivatásos állománya számára kialakított új alkalmasságvizsgálati rendszer, a KLIR rendszer jövőbeni hatékony működésének egyik záloga, ha minden olyan HR rendszer, mely kiválasztási és képzési igénnyel is párosul, ezt a rendszert tekinti kiindulási alapnak. Ennek megvalósítása érdekében a KÖFOP-2.1.5 projekt keretében jelenleg kialakítás alatt álló egységes közszolgálati mentori rendszer, valamint az új rendészeti tehetségmenedzsment rendszer is követi a KLIR rendszer kompetenciarendszerének kidolgozási módszertanát a kiválasztási kritériumként megfogalmazott kompetenciák, valamint azok mérési módszertana vonatkozásában.

Érdekességként megemlítendő, hogy szervesen illeszkedik ezen kompetenciaalapú alkalmasságvizsgálati, kiválasztási és képzési rendszer alapkoncepciójához a szilárd erkölcsiség, mint a korrupciós kihívásnak való ellenállási képesség mérésére megalkotott elméleti SZEM-modell (Hunyady \& Münnich, 2016; Papp \& Münnich, 2021), az annak mérésére kidolgozott, informatikailag támogatott interaktív tesztrendszer, valamint a kapcsolódó blended-learning képzési módszertan (Malét-Szabó et al., 2021a) is.

\section{Felhasznált irodalom}

Atkinson, R. L., Atkinson, R. C., Smith, E E. \& Bem, D. J. (1999). Pszichológia. Osiris Kiadó.

Barna B. (2020). A pályakezdő katonák megszólításának és megtartásának lehetősége a szervezeti szocializáció eszközével. Honvédségi Szemle, 148(6), 67-80. https://kiadvany.magyarhonvedseg.hu/index.php/honvszemle/issue/view/19/22

Bokodi M., Fekete L., Lóczy P. \& Szakács G. (2020). Szervezeti És Személyzeti Hatékonyság És Teljesitmény. Nemzeti Közszolgálati Egyetem. https://nkerepo.uni-nke.hu/xmlui/bitstream/ handle/123456789/14997/Szervezeti\%20es\%20szemelyzeti\%20hatekonysag\%20\%E9s\%20 teljesitmeny.pdf;jsessionid=78A54DB6403A4AC6D9A982981BB6A88D? sequence=3

Csirszka J. (1966). Pályalélektan. Gondolat Könyvkiadó.

Harrison, R. V. (1978). Person-environment fit and job stress. In Cooper, C. L. \& Payne, R. (Eds.), Stress at work (pp. 175-205). Wiley. 
Hunyady Gy., Münnich, Á. (2016). A szilárd erkölcsiség elvárása a rendvédelemben: egy lehetséges pszichológiai modell. Belügyi Szemle, 64(6), 34-68. https://doi.org/10.38146/BSZ.2016.6.2

Johnson, S., Cooper, C., Cartwright, S., Donald, I., Taylor, P. \& Millet, C. (2005). The experience of work-related stress across occupations. Journal of Managerial psychology 20(2), 178187. https://doi.org/10.1108/02683940510579803

Juhász M. (2006). A kiválasztás és a munkaköri alkalmasság pszichológiája I. rész. Munkaügyi Szemle 50(1), 21-25. http://www.munkaugyiszemle.hu/sites/default/files/Juhasz_Marta.pdf

Karasek, R., Theorell, T. (1990). Healthy work: Stress, productivity and the reconstruction of working life. Basic Books.

Kaucsek Gy. \& Simon P. (2002). A vállalati rugalmasság elemzése, Vezetéstudomány, 33(7-8), 2-17. http://unipub.lib.uni-corvinus.hu/4757/1/VT_2002n7_8p2.pdf

Malét-Szabó E. (2015). Egészség és hatékonyság: A Magyar Rendőrségen folyó pszichológiai tevékenységek kettős célkitüzése. In Balázs K. (Szerk.), Alkalmazott pszichológiai tanulmányok a Szociál- és Munkapszichológiai Tanszék fennállásának 25. évfordulójára (pp. 87-110). Debreceni Egyetemi Kiadó.

Malét-Szabó E. (2020a). A rendvédők pszichológiája. In Haller J. (Szerk.), Rendészeti pszichológia (pp. 185-242). Ludovika Egyetemi Kiadó.

Malét-Szabó E. (2020b). Mentálhigiéné és vezetői mentálhigiéné. In Farkas J. \& Haller J. (Szerk.), Pszichológia a közszolgálatban II. (pp. 75-88). Ludovika Egyetemi Kiadó.

Malét-Szabó E. (2021a). A SZEM-szemlélet születése. In Malét-Szabó E., Münnich Á. \& Takács-Fehér M. (Szerk.), Integritás a rendvédelem ,SZEM”-ével-avagy a szilárd erkölcsiség rendvédelemspecifikus jellemzői a korrupciómegelözés szolgálatában (pp. 223-232). Belügyminisztérium.

Malét-Szabó E., Kurucz Gy., Balázs K. \& Münnich Á. (2021b) Kompetenciarendszerek kialakítási és mérési módszertana a belügyi alkalmasságvizsgálati rendszerben. Belügyi Szemle, 69(8), 1361-1383.

Münnich Á. (2017). Az új belügyi vezetőkiválasztási és vezetőképzési rendszer hatékonyságvizsgálati módszertanának tudományos alapon történö elméleti kidolgozása (kivonat). Belügyminisztérium. http://www.bm-tt.hu/assets/letolt/kutat/2017/osszbtt2018.pdf

Papp G. \& Münnich Á. (2021). A szilárd erkölcsiség pszichológiai modellje. In Malét-Szabó E., Münnich Á. \& Takács-Fehér M. (Szerk.), Integritás a rendvédelem „SZEM”-ével-avagy a szilárd erkölcsiség rendvédelemspecifikus jellemzői a korrupciómegelözés szolgálatában (pp. 10-20). Belügyminisztérium.

Pásztor A. \& Szabó B. (2005). A Rendőrségen folyó egészségügyi alapellátás pszichológiai feladatkörei. Alkalmazott Pszichológia, 7(1), 30-40.

Queirós, C., Passos, F., Bártolo, A., Marques, A. J., da Silva, C. F. \& Pereira, A. (2020). Burnout and Stress Measurement in Police Officers: Literature Review and a Study With the Operational Police Stress Questionnaire, Frontiers in Psychology, 11(587), 1-23. https://doi. org/10.3389/fpsyg.2020.00587 a tudomány válasza a rendvédelmi hivatásos állomány alkalmasságvizsgálatának kihívásaira 
Szabó E. (2009). A munkahelyi egészségpszichológia és egészségfejlesztés rendszere a Magyar Köztársaság Rendörségén, valamint a szubjektive észlelt munkahelyi stresszterheltség jellegzetességei - különös tekintettel az idői tényezöre - a hivatásos állományú rendörök körében (doktori értekezés). Debreceni Egyetem. http://hdl.handle.net/2437/93931

Szabó E., Rigó B. (2005). A munkahelyi stresszmegterhelés sajátosságai a rendőrség hivatásos állományának körében. Alkalmazott Pszichológia, 7(3), 15-29.

\section{Alkalmazott jogszabályok}

1996. évi XLIII. törvény a fegyveres szervek hivatásos állományú tagjainak szolgálati viszonyáról 1993. évi XCIII. törvény a munkavédelemről

2015. évi XLII. törvény a rendvédelmi feladatokat ellátó szervek hivatásos állományának szolgálati jogviszonyáról

45/2020. (XII. 16.) BM rendelet a belügyminiszter irányítása alatt álló egyes rendvédelmi feladatokat ellátó szerveknél foglalkoztatott hivatásos állomány és rendvédelmi igazgatási alkalmazotti állomány alkalmasságvizsgálatáról

A fegyveres szervek hivatásos és szerződéses állományának egészségi, pszichikai és fizikai alkalmassága, az ideiglenes szolgálat-, keresőképtelenség, illetve az állomány megváltozott egészségi állapotú tagjai egészségügyi felülvizsgálatának elbírálásáról és a belügyi egészségügyi intézmények igénybevételéröl szóló 33/1997. IM-BM-TNM együttes rendelet

A fegyveres szervek hivatásos, közalkalmazotti és köztisztviselői állományának munkaköri egészségi, pszichikai és fizikai alkalmasságáról, a szolgálat-, illetve keresőképtelenség megállapításáról, valamint a belügyi egészségügyi szolgálat igénybevételéről szóló 21/2000. (VIII. 23.) IM-BM-TNM együttes rendelet

Az egyes rendvédelmi szervek hivatásos állományú tagjai egészségi, pszichikai és fizikai alkalmasságáról, közalkalmazottai és köztisztviselői munkaköri egészségi alkalmasságáról, a szolgálat-, illetve keresőképtelenség megállapításáról, valamint az egészségügyi alapellátásról szóló 57/2009. (X. 30.) IRM-ÖM-PTNM együttes rendelet

A belügyminiszter irányítása alatt álló rendvédelmi feladatokat ellátó szerveknél alkalmazható rendvédelmi egészségkárosodási ellátásról szóló 54/2016. (XII. 22.) BM rendelet

\section{A cikk APA szabály szerinti hivatkozása}

Malét-Szabó E. \& Takács-Fehér M. (2021). A Kétlépcsős Integrált Alkalmasságvizsgálati Rendszer - a tudomány válasza a rendvédelmi hivatásos állomány alkalmasságvizsgálatának kihívásaira. Belügyi Szemle, 69(8), 1385-1409. https://doi.org/10.38146/BSZ.2021.8.5 